\title{
Genetic basis for pulse crop improvement: collection, preservation and genetic variation in relation to needed traits
}

\section{J. G. VAN DER MAESEN}

Department of Plant Taxonomy, Wageningen Agricultural University, P.O. Box 8010, 6700 ED Wageningen, The Netherlands

W. J. KAISER

USDA-ARS, Northwest Area Regional Plant Introduction Station, 59 Johnson Hall, Washington State University,

Pullman, WA 99164, USA

\section{G. A. MARX}

Department of Horticultural Sciences, Sturtevant Hall, New York State Agricultural Experiment Station, Cornell University, Geneva, NY 14456, USA

and

\section{WOREDE}

Plant Genetic Resources Centre, Institute of Agricultural Research, Addis Ababa, Ethiopia

\section{Abstract}

The position of germplasm collections of each of cultivated pea (Pisum sativum L.), lentil (Lens culinaris Medic.), faba bean (Vicia faba L.), and chickpea (Cicer arietinum L.) is relatively safe with improving storage conditions at several centers. Duplication is present, but is also a safeguard against losses. Cultivars grown in border areas in the Middle East and Central Asia, and in areas not connected by roads (such as in Ethiopia, Iran and Afghanistan) are probably not well-represented. Wild species are also poorly represented in most collections. Special purpose collections may be needed for traits not yet available in existing collections. Clear-cut geographic patterns for the occurrence of resistance to diseases and pests have been reported for pea. Maintenance of wild species is a matter of concern, even though their potential for utilization is awaiting new genetic techniques since conventional crossing is not always possible. Screening and documentation of germplasm are ongoing activities. Data exchange is still sporadic and in widely different formats. The potential value of available germplasm for breeding is difficult to assess, since quantitatively-inherited traits and re- 
sponses to climate necessitate extensive testing. Screening usually reveals desired traits but their incorporation in cultivars is a complex task. The materials already collected could be used more extensively by plant breeders.

\section{Collections available}

After twenty years of progressively intensified efforts to preserve the germplasm of pulse crops, the conserved genepools of each of chickpea, lentil, pea and faba bean are probably quite reasonable. Previous working collections have experienced frequent losses since plant breeders have not always had the means and/or motivation or facilities to maintain large numbers of accessions. The nature of collections is also often biased, with apparently more agriculturally useful samples being collected and maintained, rather than having populations of landraces to represent available diversity. Many sizeable collections are available (Table 1), but their continued operation and expansion will depend on sustained national and international funding. Small collections are not appropriate for the maintenance of genetic diversity, but are useful if they are part of a network of genebanks. Although some duplication of samples exists, this adds to security and so may justify the expense. Moreover, a decision to eliminate material from any collection requires very specialized knowledge and exacting communication between curators. Because of these uncertainties, the expulsion of duplicates is a difficult challenge - an investment in enlarged gene bank capacity is probably preferable to an attempt to identify and remove all possible duplicates.

Numerous samples have been exchanged between collections over the years, and a majority of these collections is also represented in the designated world collections. Straightforward administrative duplicates, however, should always be double-checked: with "growouts" at one or even several locations, simple labelling errors may have occurred - or else unconscious selection, or other forms of unwanted genetic drift, might result from repeated seed increase. The question is: Should we maintain the status quo or enable evolution to continue? Annual species do evolve rather rapidly!

Documentation initially covered only location data, and then often not in detail. Material without passport data may be valuable, but its origin and history remain unclear. Reliably informative data are needed (Blixt and Williams, 1982); too many accessions are represented merely by an identification number. Searching for specific characters, be they of a passport or biological nature, is discouraging for even the zealous researcher. Systematic, comprehensive surveys by those few workers who are in a position to explore and exploit germplasm are needed; commercial breeders cannot be expected to invest very much of their time or resources on wild or primitive material. And yet, much useful variation is probably available in the wild and primitive forms. Who shall do the work, and who shall underwrite the costs of such work? The publicly funded national and international research 
Table l. Accessions of cool season food legumes in major germplasm collections.

Institute and location Species conserved

Cicer Lens Pisum Vicia sect. faba

1. Ege Agric. Res. Introd. Centre

Menemen, Turkey

2. Ethiopian Genebank Addis Ababa, Ethiopia

3. Geneva Pisum Collection Geneva, NY, USA

4. Germplasm Laboratory Bari, Italy

5. ICARDA Aleppo, Syria

6. ICRISAT Patancheru, India

7. INIA Mexico City, Mexico

8. John Innes Institute Norwich, England

9. NBPGR New Delhi, India

10. Netherlands Genebank Wageningen, The Netherlands

11. Nordic Genebank Lund, Sweden

12. NSSL Fort Collins, CO, USA

13. Pakistan Agr. Res. Council Islamabad, Pakistan

Cicer

USDA NE Reg. Station Geneva, NY, USA

15. USDA NW Reg. Station Pullman, WA, USA

16. Vavilov Inst. PI. Industry Leningrad, USSR

17. ZG Kulturpfl. 717 413 2000

717

2000

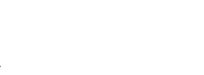

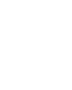

- Gatersleben, DDR

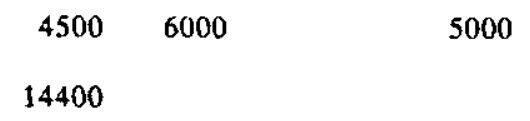

1600

- Other sections also included.

institutes obviously play an important role, and, indeed, it is they who have done much of the work.

References on genetic resources work in grain legumes have been comprehensively synthesised in various workshop proceedings, compilation works and, most recently, in Grain Legume Crops (Summerfield and Roberts, 1985). Specialized legume newsletters encourage rapid exchange of information (e.g. see pp. 22-23, this Volume). 


\section{Current gaps and future work}

Gaps in the current collections may be classified into four categories: geographic, taxonomic, administrative and special-purpose stocks.

Geographic gaps occur when regions known or thought to contain diversity have either not been collected or sampled only inadequately. These gaps include areas of difficult geographic or political access, such as regions not linked by roads or those in border areas. On the other hand, few areas are now really physically inaccessible, and sparse populations and isolation do not necessarily assure the presence of unique plant germplasm. For instance, markets in Chakcharan (Central Afghanistan) offered chickpea samples originating from various villages, all known by name and even by their distance. Some experts are optimistic that conserved landrace populations may harbour much of the available diversity already. Yet, more samples of individual, isolated wild and primitive plants known not to be escapes from cultivation are needed. These will be the precise starting points for a discussion of genetic relations.

Taxonomic gaps are formed when taxa which have been described and are available as herbarium material are not yet or are no longer available as seed. Large numbers of named cultivars of these four crops have been superseded, and the older ones are not always kept. In the west, old horticultural cultivars have retained some foothold as relic crops, or in the hands of devoted amateurs. In the east, retention of old but useful or desirable cultivars is a long-standing tradition. Still, improved cultivars continue to replace less productive landraces. The genepool of related wild species is a special case. Germplasm of no pulse crop is complete: not all species or taxa of lower rank are available, and some so rare that they may have even become extinct. Although few or perhaps no species may hybridize with the cultigen (e.g. as in Cicer and Vicia faba), the potential benefits of having the wild species to hand, when required, warrants their maintenance in one or more germplasm collections. Table 2 attempts to summarize taxonomic gaps and sources of material where those gaps are at least represented in more detail. The likelihood of detecting undescribed species or varieties has become small, but not impossible: e.g. the recently described Cicer canariense (Santos Guerra and Lewis, 1986) - it seems that the relatively well-collected Canary Islands can even be a source of novelties.

Administrative gaps are in part taxonomic ones. These refer to the numbers of accessions once present in a collection, and which have not been kept, but which may be represented by other, similar (even identical) material. No-one is to blame: up to the 1960 's most plant breeders kept only material of immediate use, with certain qualities and adaptation to their region of concern.

Genetic stock gaps arise when accessions with special attributes are not known to be available, but are nevertheless needed for crop improvement. When large collections are screened effectively, these gaps are usually at least 
Table 2. Taxonomic gaps in cool season food legume germplasm collections.

\begin{tabular}{|c|c|c|c|}
\hline Species & & Material & Source \\
\hline Cicer & $\begin{array}{l}\text { (a) } \\
\text { (b) } \\
\text { (c) }\end{array}$ & $\begin{array}{l}27 \text { out of } 35 \text { perennial species were never available as } \\
\text { viable sceds } \\
8 \text { perennial species - accessions very few } \\
8 \text { wild annual species - accessions very few }\end{array}$ & $\begin{array}{l}\text { ICRISAT } \\
\text { (personal } \\
\text { experience of } \\
\text { senior author) }\end{array}$ \\
\hline Lens & $\begin{array}{l}\text { (a) } \\
\text { (b) }\end{array}$ & $\begin{array}{l}\text { L. culinaris-grex subspontanae hardly available } \\
\text { wild species - accessions few }\end{array}$ & $\begin{array}{l}\text { Muchlbauer } \\
\text { et al. (1985) }\end{array}$ \\
\hline Pisum & & $\begin{array}{l}\text { wild forms - especially seeds from individual plants } \\
\text { growing in isolated, diverse environments }\end{array}$ & $\begin{array}{l}\text { G. A. Marx } \\
\text { (pers. comm., } \\
\text { and see } 1985 \text { ) }\end{array}$ \\
\hline Vicia faba & $\begin{array}{l}\text { (a) } \\
\text { (b) } \\
\text { (c) }\end{array}$ & $\begin{array}{l}\text { cv. group Paucijuga - accessions few } \\
\text { real wild faba bean never found } \\
\text { Vicia narbonensis-group sufficient in collections }\end{array}$ & $\begin{array}{l}\text { J.1. Cubero } \\
\text { (pers. comm.) }\end{array}$ \\
\hline
\end{tabular}

partly filled, and the remainder of the collection is then maintained to preserve the genes concerned for ten, fifty or $\geqslant 100$ years. Successful screening (Marx, 1985) for a given trait may lead to information about where additional material with the same or similar desired trait or attribute might also be found. It is to advantage that breeders undertake such biased sampling along with their general-purpose collections, such as takes place, for example, in Ethiopia. Clear geographic patterns for the occurrence of particular traits have now been indicated for disease resistance in pea (Hampton, 1986). The contention that resistance may be found in specific areas with long-standing disease pressure (the so-called "hot spots") needs to be verified for other disease complexes, but circumstantial evidence for SbMV (pea seedborne mosaic virus) shows a strong relation between the presence of the disease and genotypes of pea resistant to it in North India (Hampton, 1986).

Future collection work will need to follow after detailed scrutiny of the available records in order to cover obvious gaps and to avoid obvious duplication. Suggestions for areas to be searched for Cicer species are listed by van der Maesen and Pundir (1984), and IBPGR priority areas for all four species are summarized in Table 3 (IBPGR, 1981). Opportunity and political accessibility are important factors bearing on the decision to explore or re-explore certain areas.

\section{Taxonomy and geographic centres of diversity}

A recent and generalized update of the taxonomic framework of grain legumes is given by Polhill and van der Maesen (1985); the taxonomy of Pisum, Lens, Vicia section Faba and Cicer was also reviewed. Of course, 
Table 3. IBPGR priorities ${ }^{2}$ for some cool season food legumes.

\begin{tabular}{lll}
\hline Species & Prionity & Regional priority \\
\hline Cicer & 2 (second) & 1 (first) in S.W. Asia \\
Lens & 3 (third) & 1 (first) in S.W. Asia \\
Pisum & 3 (third) & Information not given \\
Vicia faba & 3 (third) & 1 (first) in Mediterranean \\
\hline
\end{tabular}

- The priorities given are an over-all assessment of the urgency for collection; for considerations, see IBPGR (1981).

opinions differ regarding the rank of certain subgeneric or subspecific taxa, but the fact that these taxa exist is evidence of distinct differences. The most recent review of Cicer is given by van der Maesen (in press, and see 1984b), which follows his earlier monograph (1972). A listing of the taxa belonging in the genepool of the four crops of topical concern is presented in Table 4. The taxonomy of the tribes Cicereae and Vicieae has been treated by Kupicha $(1976 ; 1977 ; 1981)$ and by Cubero $(1981)$.

Pisum inhabits the Mediterranean and the Near East, Turkey and Iran; regions where considerable genetic diversity exists. Four possible centers of diversity are known: the Near East, the Mediterranean, Central Asia and Ethiopia. Wherever in temperate zones or seasons peas can be grown, the crop has spread around the world either as a dry pulse or a vegetable. Pisum humile Boiss. \& Noë (now P. sativum L. subsp. elatius (M. Bieb.) Aschers. \& Graebn. var. pumilio Meikle) is now generally considered to be the wild form of the cultivated pea, but specialists do not all agree. Apart from Pisum sativum, the only remaining species is $P$. fulvum Sibth. \& Smith from the Eastern Mediterranean. (The perennial Vavilovia formosa (Stev.) Fed. was formerly incorporated in Pisum as $P$. formosus (Stev.) Alef.).

Lens (sub)species occur around the Mediterranean. There is still a lack of the wild (sub)species in germplasm collections, most of which are represented by only a few accessions. Barulina's work (1930) is still a good source of information on the geography of cultivated lentil, but living collections may give a more complete picture of distribution. Barulina's grex (groups) retain usefulness, describing the forms present in India, Ethiopia, the Near East and the Mediterranean. Lens montbretii (Fisch. \& Mey.) Davis \& Plitm. may in fact be a Vicia, but is known from only a few herbarium specimens and so live specimens are required for further clarification.

Vicia faba originated in one or more regions between the Mediterranean area and Afghanistan. Most areas are well represented in collections. The related narbonensis complex occurs in the Mediterranean area and the Middle East. Some species are narrow endemics of Turkey and Israel. The range available in living collections is definitely quite small (Cubero, 1984). 


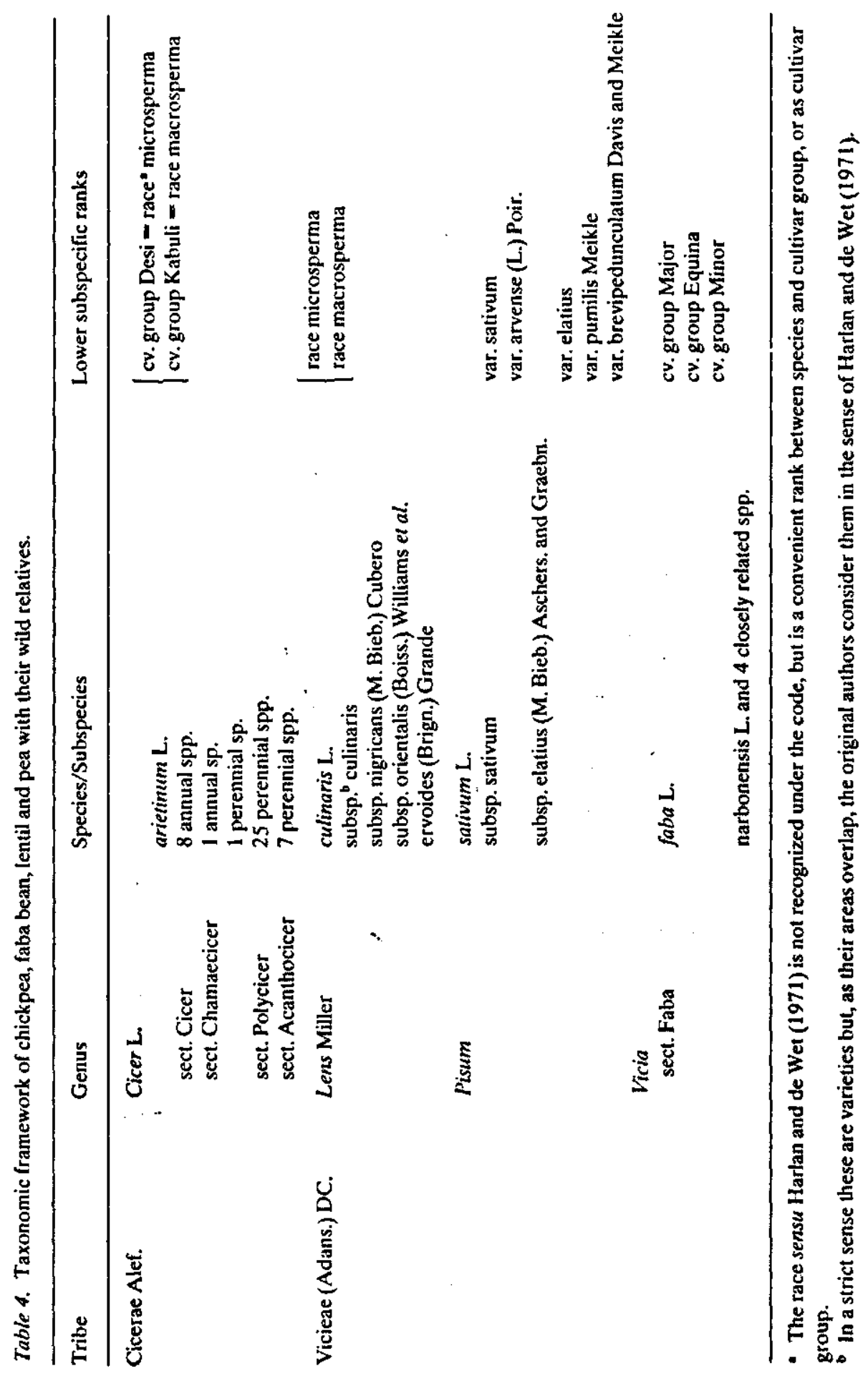


Cicer species are distributed from the Canary Islands to Burma. In the new world, chickpea is widely cultivated in Mexico, Chile and Peru, and is grown to some extent in Canada and the USA. Some wild species have a narrow endemic range: for instance Cicer canariense Santos Guerra \& Lewis from Tenerife and la Palma in the Canary Islands; $C$. atlanticum Cosson ex Maire in the Atlas Mountains of Morocco; $C$. graecum in the Peloponnese of Greece; and $C$. heterophyllum Contandr. et al. from the Taurus Mountains in Turkey. No other species is really common. The Western and Eastem Mediterranean, Asia Minor, Central Asia, Iran and Afghanistan have the greatest wealth of Cicer species. India and Ethiopia are centers of diversity of the cultivated chickpea. The crop in Mexico and Chile is of recent (postColumbian) introduction, but has achieved local adaptation. Chickpea cultivars from the Caucasus, Central Asia and off-the-road Ethiopia are still lacking from the world collections, but this gap is being remedied. The ICRISAT priority areas for chickpea are the Indian subcontinent (of which adjacent Burma may well have more diversity to offer), Afghanistan, Iran and Turkey, the Central Asian Soviet Republics, Ethiopia and parts of North Africa (ICRISAT, 1985). Apart from Burma, priorities are no longer assigned by nation, but by region.

Comparison of passport data with collection details is needed to determine where to explore in the centers of diversity more extensively. For wide crosses in Vicieae, the genus Lathyrus might also be considered. A peculiar lentil-like Vicia is V. lunata (Boiss. et Bal.) Boiss.

\section{Evolution and domestication}

Centers of domestication or diversity of the grain legumes are largely known, although closely defined areas will remain difficult to specify. Knowledge of the distribution of purported ancestral forms is still incomplete (Smartt and Hymowitz, 1985). For the four pulses under consideration here, domestication could have occurred in more than one center in the Meditteranean, Asia Minor and Central Asia, or else early distribution gave rise to secondary centers such as in Ethiopia. Figure 1 summarizes the probable origin and distibution of each of chickpea, lentil, pea and faba bean.

The changes brought about in grain legumes under domestication (Schwanitz, 1966) are obvious increases in seed size (gigantism, allometric growth), reduction or loss of pod dehiscence for natural dissemination, biochemical changes (e.g. loss of toxins), loss of seed dormancy, changes in branching pattern, and differences in morphology and life form. All of the four pulses under discussion here are annuals, all except nine species of Cicer are perennial, while the other three pulses do not have closely related perennials.

Archaeological, anthropolugical, historical and linguistic evidence combined has contributed to a reasonably, if not always complete or unequivocal, account of domestication. For chickpea, reviews are given by van der Maesen 


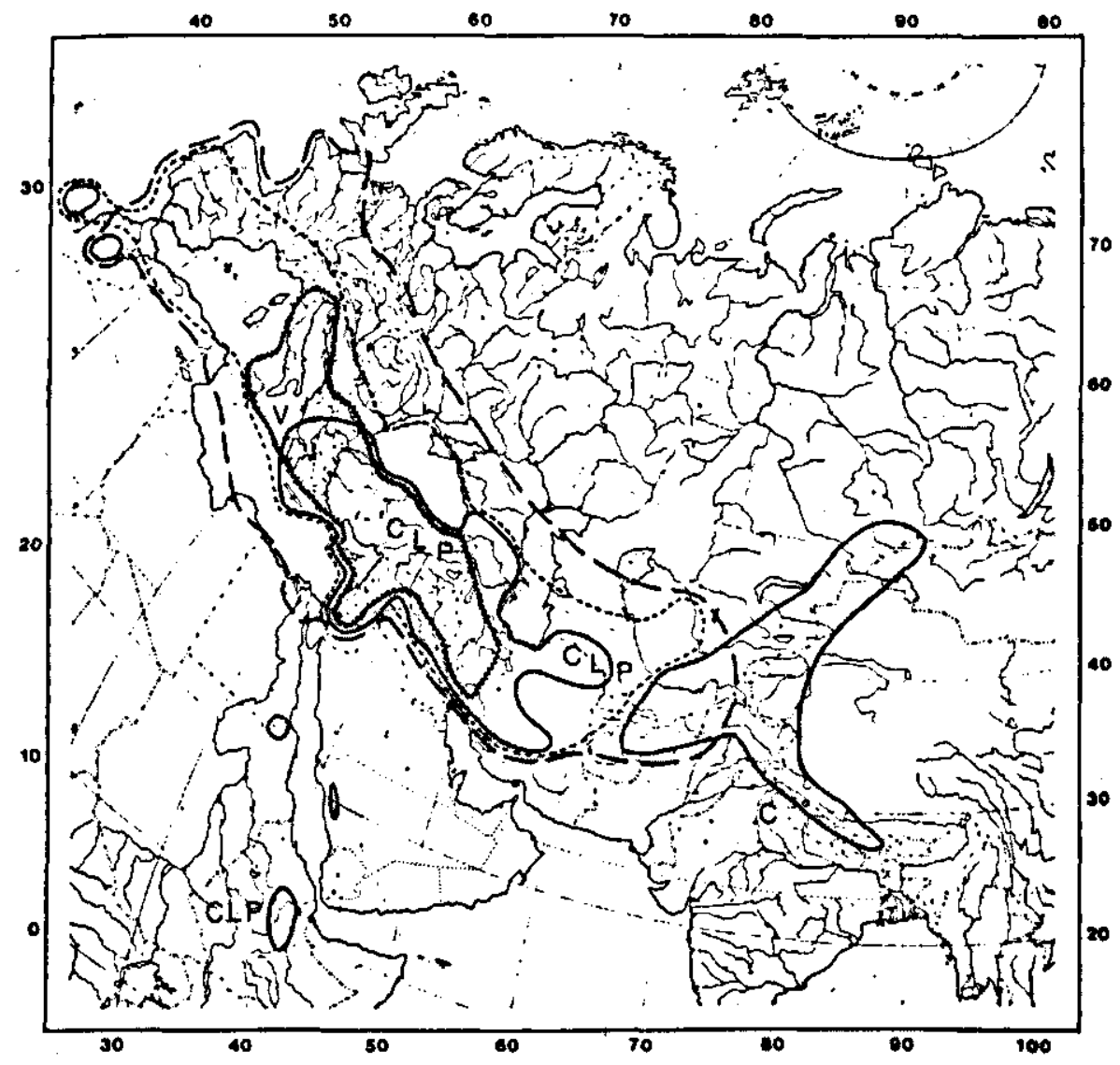

Fig. I. Probable origin and distribution of grain legumes. P, L, V and C denote centres of diversity of cultivated pea, lentil, faba bean and chickpea. Wild Pisum forms (mm), wild Lens spp. (-.-), Vicia sect. faba $(--)$ and wild Cicer spp. $(-)$.

(1972; 1984b; in press); for lentil by Cubero (1981) and Muehlbauer et al. (1985); and for faba bean and pea by Zohary and Hopf (1973), Bond (1976), Cubero (1984), and Davies (1976). The Near East and Eastern Mediterranean, in particular the Fertile Crescent, have yielded many carbonized remains, usually of small-seeded forms. The earliest Neolithic pea remains date back to $7000 \mathrm{BC}$, and lentil, with their characteristic shape, date back to $8000 \mathrm{BC}$. The picture for faba bean is a diffuse one, as many remains have been found in the late Neolithic and Bronze Ages all over Europe and the Aegean. Chickpea is found in small numbers, as the typical beak on seeds suffers damage in deposits. The oldest find is from Western Anatolia and dated to $5450 \mathrm{BC}$.

A linguistic study of vernacular names of grain legumes would be interesting. Most botanical studies are confined to lists and a few suggestions of 
similarity, while etymology has not compared pulse vernaculars in a single study.

\section{Conservation of pulse germplasm}

The following comments are not exhaustive and detailed treatments of the subject can be found in the references cited. Grain legume seeds are classified as "orthodox," that is they can be stored at low seed miosture content (below $7 \%$ ) and at low, preferably sub-zero, temperatures $\left(-18^{\circ}\right.$ to $\left.-20^{\circ} \mathrm{C}\right)$. Since 1978 (van der Maesen, 1979) the situation of cold-storage facilities at genebanks has improved considerably. Those at Bari, Izmir, ICARDA, ICRISAT, and Pullman all have medium-term facilities $\left(+5^{\circ} \mathrm{C} ; \pm 35 \% \mathrm{RH}\right.$ ), and several institutions have long-term deep-freeze rooms as well (and see Ellis et al., 1985; Roberts, 1972; 1975; and van der Maesen, 1984a).

Sample size is often a matter of convenience, with the size of the containers determining the maximum size of the samples retained. For large-seeded grain legumes, containers vary between 0.5 and $2.5 \mathrm{l}$. In principle, sample sizes should approach 4000 seeds for self-pollinated crops, and 12000 for cross-pollinated ones. The four grain legumes of concern here are usually maintained by natural or artificial selfing. If selfing is impossible, then attempts should be made to maintain population samples as close to their original condition as possible. The best way to do this is to store large initial base samples $(1 \mathrm{~kg})$ to provide seed for regeneration, and to be able to fall back to the original sample without increasing many generations. Seed supply is then possible from samples regenerated only once; the ideal of supplying original seed is usually impractical.

Handling of germplasm has been described comprehensively by Cromarty et al. (1982), van der Maesen (1984a), and Ellis et al. (1985), but practice varies from station to station. With simple equipment and methods, for example, much can be done for active collections, such as (hand) harvesting seeds in the dry season, sun drying, use of locally available containers, and commercial cold storage. For long-term storage (base collections), more exacting precautions (such as drying chemically at moderate temperatures) are needed.

Viability graphs (nomographs) (Roberts, 1972; Ellis et al., 1985) show the time taken for viability to fall to any given value at given combinations of temperature and moisture content.

Two factors are of particular concern in germplasm collections: genetic shift, caused by differential rates of deterioration and regeneration; and mutation. Mutation is the lesser evil, because even if the mutation survives (usually on a cell basis), it increases the genetic diversity. Genetic shifts lead to a narrowing of the genetic base, and are more serious (Roos, 1985). Loss in viability is directly correlated with genetic changes. Artificial ageing, computer simulations and electrophoresis are among various techniques that might be employed in future research on improved seed storage. 
Mechanical mixing of samples during maintenance is a serious problem. Once the seeds become mixed through error or negligence, the variation can still be considered sacrosanct and to merit preserving, but this attitude is questionable. On-site preservation is useful but difficult to arrange and monitor. Nevertheless, it should not be neglected. Multiplication in areas in close proximity to the place of collection is often called for but the benefits are often exaggerated, especially in the case of self-pollinated crops.

\section{Utilisation of germplasm}

There is a need to emphasize and encourage the wider use of existing diversity in the germplasm collections. Wild and primitive forms are not yet used to the extent anticipated (Marx, 1985). But, the dangers of uniform genotypes of crop plants cultivated over large areas are real, as are the risks of new pathotypes of diseases, or resistant pests. Genetic erosion needs to be addressed by genetical means; by the incorporation of genes from widely different sources. Use of standard descriptors (e.g., IBPGR, 1985) facilitates data exchange when material is evaluated.

\section{Bibliography}

Barulina, H. (1930). [Lentils of the USSR and other countries]. Suppl. 40, Bulletin of Applied Botany, Genetics and Plant Breeding: 265-304.

Blixt, S. and Williams, J. T., Eds (1982) Documentation of Genetic Resources: A Model. Proceedings of a Workshop held in Lund, 1982. Rome: International Board for Plant Genetic Resources.

Bond, D. A. (1976). In Evolution of Crop Plants, pp. 179-182 (Ed. N. W. Simmonds). London \& New York: Longman.

Cromarty, A. S., Ellis, R. H. and Roberts, E. H. (1982). The Design of Seed Storage Facilities for Genetic Conservation. pp. 96. Rome: IBPGR.

Cubero, J. 1. (1981). In Lentils, pp. 15-38 (Eds C. Webb and G. C. Hawtin). Commonwealth Agricultural Bureaux/ICARDA.

Cubero, J. I. (1984). In Genetic Resources and their Exoloitation - Chickpeas, Fababeans and Lentils, pp. 131-144 (Eds. J. R. Witcombe and W. Erskine). Dordrecht: Martinus Nijhoff, Dr. W. Junk Publishers, ICARDA.

Davies, D. R. (1976). In Evolution of Crop Plants, pp. 172-174 (Ed. N. W. Simmonds). London \& New York: Longman.

Ellis, R. H., Hong, T. D. and Roberts, E. H. (1985). Handbook of Seed Technology for Genebanks, Vol. 1, Principles and Methodology; Vol. 2, Compendium of Specific Germination Information and Test Recommendations. pp. 210 and 667. Rome: IBPGR.

Hampton, R. O. (1986). Pisum Newsletter 18: 22-26.

Harlan, J. and de Wet, J.M. J. (1971). Taxon 20: 509-517.

IBPGR (1981). Revised Priorities among Crops and Regions. 18 pp. Rome: IBPGR.

IBPGR/CARDA/ICRISAT (1985). Chickpea descriplors. 15 pp. Rome: IBPGR.

ICRISAT (1985). Annual Report for 1984. Patancheru: ICRISAT.

Kupicha, F. K. (1976). Notes of the Royal Botanic Garden Edinburgh 34: 287-326.

Kupicha, F. K. (1977). Botanical Journal of the Linnaean Sociery 74: 131-162.

Kupicha, F. K. (1981). In Advances in Legume Systematics Vol. 1, pp. 377-382 (Eds R. M. Polhill and P. H. Raven). London: HSMO. 
Marx, G. A. (1985). In The Pea Crop, pp. 45-54 (Eds P. D. Hebblethwaite, M. C. Heath and T. C. K. Dawkins). London: Butterworths.

Muehlbauer, F. J., Cubero, J. I. and Summerfield, R. J. (1985). In Grain Legume Crops, pp. 266-311 (Eds R. J. Summerfield and E. H. Roberts). London: Collins.

Polhill, R. M. and van der Maesen L. J. G. (1985). In Grain Legume Crops pp. 3-36 (Eds R. J. Summerfield and E. H. Roberts). London: Collins.

Roberts, E. H. (1972). (Ed.) Viability of Seeds. London: Chapman and Hall.

Roberts, E. H. (1975). In Crop Genetic Resources for Today and Tomorrow, pp. 269-296

(Eds O. H. Frankel and J. G. Hawkes). Cambridge: University Press.

Roos, E. (1985). ISTA News Bulletin 82: 3-4.

Santos Guerra, A. and Lewis, G. (1986). Kew Bulletin 41-2: 459-462.

Schwanitz, F. (1966). The Origin of Cultivated Plants. Cambridge (Mass.): Harvard University Press.

Smart, J. and Hymowitz, T. (1985), In Grain Legume Grops, pp. 37-72 (Eds R. J. Summerfield and E. H. Roberts). London: Collins.

Summerfield, R. J. and Roberts, E. H. (Eds) (1985). Grain Legume Crops. London: Collins.

van der Maesen, L. J. G. (1972). Cicer L., a monograph of the genus, with special reference to the chickpea (Cicer arietinum L.), its ecology and cultivation. Meded. Landbouwhogeschool Wageningen 72-10, pp. 342.

van der Maesen, L. J. G. (1979). In Food Legume Improvement and Development, pp. 140146, (Eds G. C. Hawtin and G. Chancellor). ICARDAMDRC.

van der Maesen, L. J. G. (1984a). In Genetic Resources and their Exploitation - Chickpeas,

Fababeans and Lentils, pp. 13-22 (Eds J. R. Witcombe and W. Erskine). The Hague: Martinus Nijhoff/Dr W. Junk Publishers/ICARDA.

van der Maesen, L. J. G. (1984b). In Genetic Resources and their Exploitation - Chickpeas, Fababeans and Lentils, pp. 95-104 (Eds J. R. Witcombe and W. Erskine). The Hague: Martinus Nijhoff. Dr W. Junk Publishers/ICARDA.

van der Maesen, L. J. G. (in press). Origin, history and taxonomy of chickpea. In The Chickpea (Eds K. B. Singh and M. C. Saxena). ICARDA.

van der Maesen, L. J. G. and Pundir, R. P. S. (1984). Plant Genetic Resources Newsletter 57: 19-24.

Zohary, D. and Hopf, M. (1973). Science 182: 887-894. 